\title{
IMPROVING MILD STEEL CORROSION RESISTANCE IN TAP WATER: INFLUENCE OF WATER FLOW AND SUPPLY RATES
}

\author{
G. Vasyliev $^{1}$ \\ ${ }^{1}$ National Technical University of Ukraine "Igor Sikorsky Kyiv Polytechnic Institute", \\ 37, Prospect Peremohy, Kyiv-56, 03056, Ukraine, g.vasyliev@kpi.ua
}

DOI: https://doi.org/10.20535/2218-930022021236684

The mild steel corrosion has been studied in hot tap water $\left(50^{\circ} \mathrm{C}\right)$ using linear polarization technique in the laboratory set-up that models water circulating system. The influence of water flow rate $(0.15-0.45 \mathrm{~m} / \mathrm{s})$ and water supply rate $(0-70 \%$ of system volume per hour) on corrosion kinetics have been investigated. The corrosion products, formed on the surface of the steel corrosion probes, have been analysed with X-Ray Diffraction (XRD). It has been found, that in condition of low water flow rate $(0.15 \mathrm{~m} / \mathrm{s})$ and in the absence of water supply the corrosion rate is high $\left(0.29 \mathrm{~mm} /\right.$ year) due to low blocking abilities of the surface deposits. Amorphous $\mathrm{Fe}(\mathrm{OH})_{3}$ is the main corrosion product to be detected on the surface. The increase in water flow rate above $0.15 \mathrm{~m} / \mathrm{s}$ and water supply rate above $30 \%$ of system volume per hour leads to the 1.6 times corrosion rate reduction (to $0.18 \mathrm{~mm} / y$ ear) due to the formation of dense surface layer of calcium carbonate and iron oxyhydroxides. The results obtained can be utilized to improve the corrosion performance of hot water supply systems.

Keywords: corrosion rate, flow rate, mild steel, polarization resistance, tap water

Received: 6 July $2021 \quad$ Revised: 25 August $2021 \quad$ Accepted: 5 October 2021

\section{Introduction}

Corrosion processes in water supply systems is one of the key problems causing water quality deterioration, irregularity of water supply and shortage of pipeline operation time. The search of novel efficient ways of corrosion rate reduction, both efficient and environmentally safe is a challenging task of nowadays (Valdez 2010; Hilbert 2006; Lyon 2010; Antoun 1999; Henderson 1998).

A promising approach in corrosion rate reduction of mild steel pipelines is based on utilization of protective properties of surface layers, formed on the steel surface during operation in corrosive media. The corrosion process of mild steel in tap water usually combines two electrochemical reactions: anodic dissolution of iron to form $\mathrm{Fe}^{2+}$ ions and cathodic oxygen reduction to form $\mathrm{OH}-$ ions. In conductive water media these reactions take place at different parts of the surface, namely cathodic and anodic regions. Soon after formation, the products of electrochemical reactions participate in further transformations with water and salts, presented in water. $\mathrm{Fe}^{2+}$ ions are oxidized by $\mathrm{O}_{2}$ to $\mathrm{Fe}^{3+}$ ions, which hydrolyses to form $\mathrm{Fe}(\mathrm{OH})_{3}$. The dehydration of $\mathrm{Fe}(\mathrm{OH})_{3}$ leads to the formation of iron oxyhydroxides and oxides. The $\mathrm{OH}^{-}$ions, formed at the cathodic regions, react with hydrocarbonates $\mathrm{HCO}_{3}{ }^{-}$to form $\mathrm{CO}_{3}{ }^{2-}$ and thus calcium carbonate 
precipitate at cathodic sites (Tamura 2008; Elbeik 1986).

The insoluble substances formed on the surface of mild steel during corrosion may act as a barrier for oxygen supply to the surface thus reducing corrosion rate. However, the blocking efficiency of the barrier layer depends on its structure and formation conditions. High content of hardness salts results in faster formation of carbonates at cathodic sites and thus enhances the rate of barrier layer formation (Deslouis 1998; Vasyliev 2017).

The presence of magnesium ions changes the allotropic modification of calcium carbonate from calcite to aragonite crystals, which are more compact, thus the carbonate layer possesses lower porosity (Vasyliev 2014). Water flow rate is another crucial factor influencing the properties of barrier layer (Liang 2013). Low flow rate reduces oxygen supply; however, the formation of surface layers is also inhibited, and the corrosion progresses. The rise of water flow rate increases oxygen and calcium supply, the layer forms faster and corrosion rate decreases. Previously, it was shown that the corrosion rate halves when flow rate rises from 0.15 to $0.45 \mathrm{~m} / \mathrm{s}$ (Vasyliev 2015). Further rise of flow rate may cause deposits erosion and increase of corrosion rate. These findings were obtained in conditions of continuous supply of oxygen and hardness salts. However, in closed water circulation systems, i.e. how water supply systems of apartment houses, water supply may vary during the day, so oxygen and calcium may be depleted. In this condition, the maintenance of protective surface layer is no longer possible.

The aim of the present work is to investigate the influence of both the water flow rate and water supply rate on the formation of surface layers on mild steel in conditions of hot water supply operating system, determine the layer formation rate, its protection properties, structure and suggest practical recommendations to improve performance of hot water supply systems.

\section{Materials and Methods}

To study the influence of water flow rate and supply rate on corrosion processes laboratory set-up has been designed (Fig. 1). The set-up creates the models how hot water supply system operates. It includes a closed water loop made of $\varnothing 50 \mathrm{~mm}$ polypropylene pipes of 61 volume, a centrifugal pump, and a water heater $(1.5 \mathrm{~kW})$. Fresh water was supplied from the vessel, placed above the loop. The excess water is removed from the loop from its top point when a portion of fresh water is added.

The loop contains three corrosion probes with a pair of cylinder-shaped mild steel electrodes ( $\varnothing 6 \mathrm{~mm}$, length $30 \mathrm{~mm}$ ), made from mild steel St20 (European analogue Fe37-3FN). This steel was used as an electrode material because its composition is the same as for water pipelines, however its quality is better, so the corrosion rate data is reproducible.

The corrosion probes are connected to the corrometer which utilizes linear polarization technique (LPR) to determine the instantaneous corrosion rate. LPR is measured in galvanostatic polarization mode, the current of $5 \mu \mathrm{A} / \mathrm{cm} 2$ density is applied for 40 sec to the probe. After the polarization, the determined polarization resistance value is calculated in corrosion rate of mild steel ( $\mu \mathrm{m} /$ year) using conventional $B$ value of 26 
mV (Vasyliev 2017; Herasymenko 2009; Vasyl'Ev 2013; Vasyliev 2013). The probes were the only metal elements in the system to

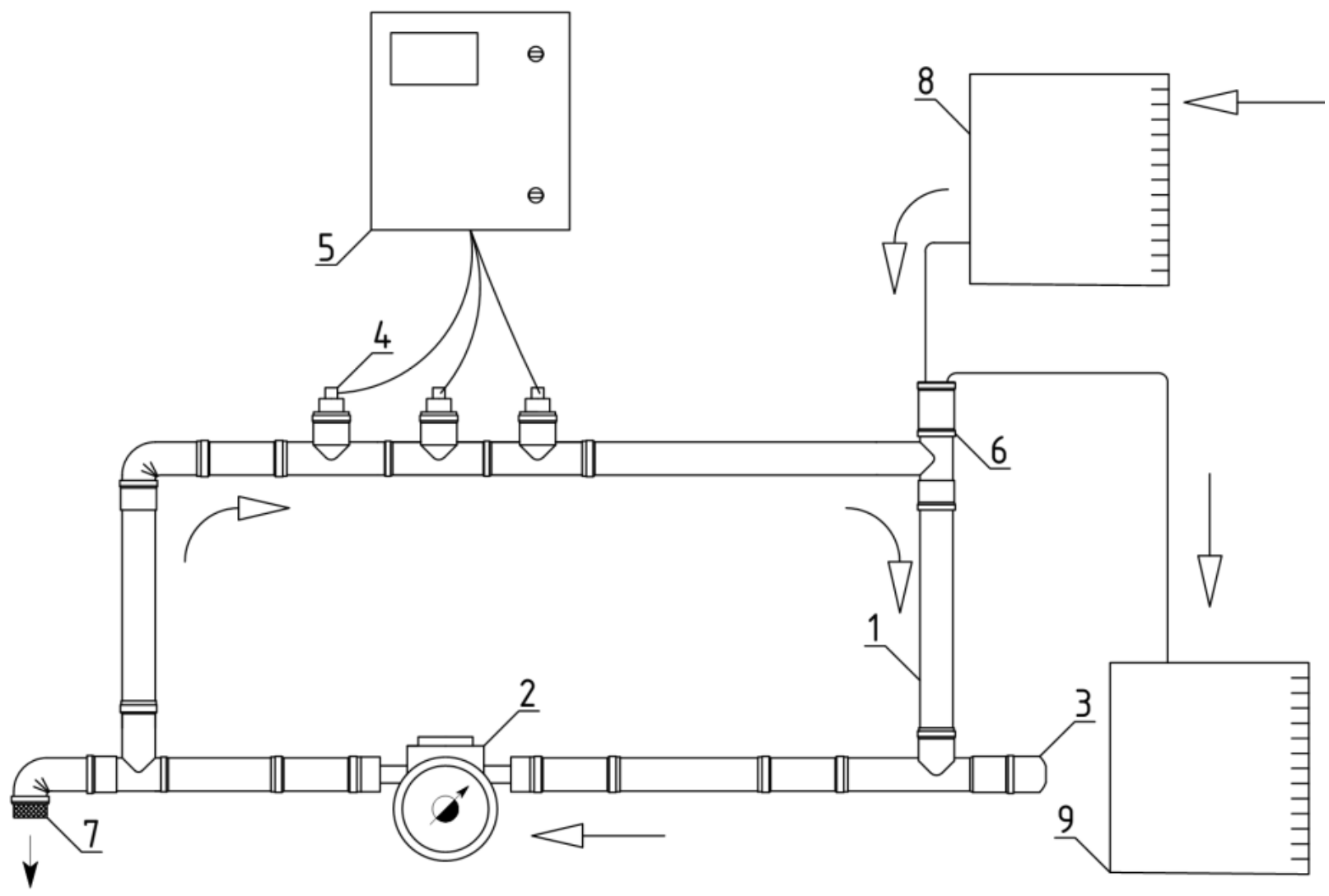

ensure that the corrosion process undergoes only on the electrodes and where the corrosion rate can be measured.

Fig. 1. The scheme of laboratory set-up that models hot water supply system: 1 -closed water loop; 2 - centrifugal pump; 3 - electric heater; 4 - corrosion probes; 5 - corrometer; 6 - water inlet; 7 -drain fitting; 8-fresh water tank; 9 -waste water tank.

The loop was filled with tap water of the following composition: Total hardness $200 \mathrm{mg} / \mathrm{l}$ as $\mathrm{CaCO}_{3}$, Total dissolved solids $250 \mathrm{mg} / \mathrm{l}$, Chlorides - $20 \mathrm{mg} / \mathrm{l}$, Sulphates $30 \mathrm{mg} / \mathrm{l}$, Dissolved oxygen $-8 \mathrm{mg} / \mathrm{l}$. Three water flow rates were tested, namely 0.15 , 0.30 and $0.45 \mathrm{~m} / \mathrm{s}$ at three water supply rates $-0,35$ and $70 \%$ of system volume per hour, 9 runs in total. Each run was performed for 2 weeks.

In each run electrodes of the corrosion probes were polished, degreased, activated in $200 \mathrm{~g} / \mathrm{l} \mathrm{HCl}$ and the probe was installed into the loop. Once the loop was filled with fresh water, circulation, heating and water supply were started. LPR measurements were conducted automatically every $15 \mathrm{~min}$ for each probe. The water temperature was kept at $50 \pm 2{ }^{\circ} \mathrm{C}$ throughout the test. The heating and circulation were maintained during daily hours -6 hours a day. In night hours and on weekends the set-up was turned off, but the water was kept inside the loop. After two weeks, the electrodes were removed from the loop, dried in hot flowing air, and sent to XRD analyses. LPR-time dependences were used to analyse corrosion rate vs time dependences.

The X-ray diffraction phase analysis (XRD) of deposits was performed using a Rigaku Ultima-IV powder X-ray diffractometer with $\mathrm{Cu} \mathrm{K} \alpha$ radiation $(30 \mathrm{kV}$ 
and $30 \mathrm{~mA}$ ). Full X-ray diffraction patterns were recorded for the scan angles $(2 \theta)$ from 20 to $80^{\circ}$ with a step size of $0.04^{\circ}$. Using the ICDD-PDF database, individual crystalline phases were identified from their observed XRD patterns.

\section{Results \& Discussion}

The LPR corrosion rate vs time dependences are given in Fig. 2. For all the tested flow rates, the dependences have similar behaviour. The initial corrosion rate is extremely high - around 2 mm/year independently of experimental conditions. Soon after the start of the test corrosion rate decreases, reaching the steady value in 100 hours. To compare the results obtained in all 9 experiments the corrosion rate - time dependences were approximated with power function of the following form (1):

$$
i=i_{0}+A \cdot e^{R_{0} \cdot \tau},
$$

where $i$ is an instantaneous corrosion rate, $\mathrm{mm} /$ year; $\left(i_{0}+A\right)$ is an initial corrosion rate, $\mathrm{mm} /$ year; $i_{0}$ is a steady corrosion rate, $\mathrm{mm} /$ year; $R_{0}$ is a rate of corrosion reduction. The diagrams, showing simultaneous influence of the water flow rate and water supply rate are given in Fig. 3 .

The initial corrosion rate of mild steel in hot tap water rises from 1.2 to $1.5 \mathrm{~mm} / \mathrm{year}$ while flow rate rises from 0.15 to $0.45 \mathrm{~m} / \mathrm{s}$. Water supply rate has practically no influence on this parameter. Such a dependence agrees with a diffusion character of oxygen reduction on freshly treated metal surface. The increase in water flow rate makes the diffusion layer thinner thus raising the corrosion current.

The steady corrosion value appeared to be influenced by both water flow and water supply rate. In conditions when no fresh water is added to the system, calcium and oxygen are soon depleted and the surface layer on the steel surface possesses low blocking abilities.
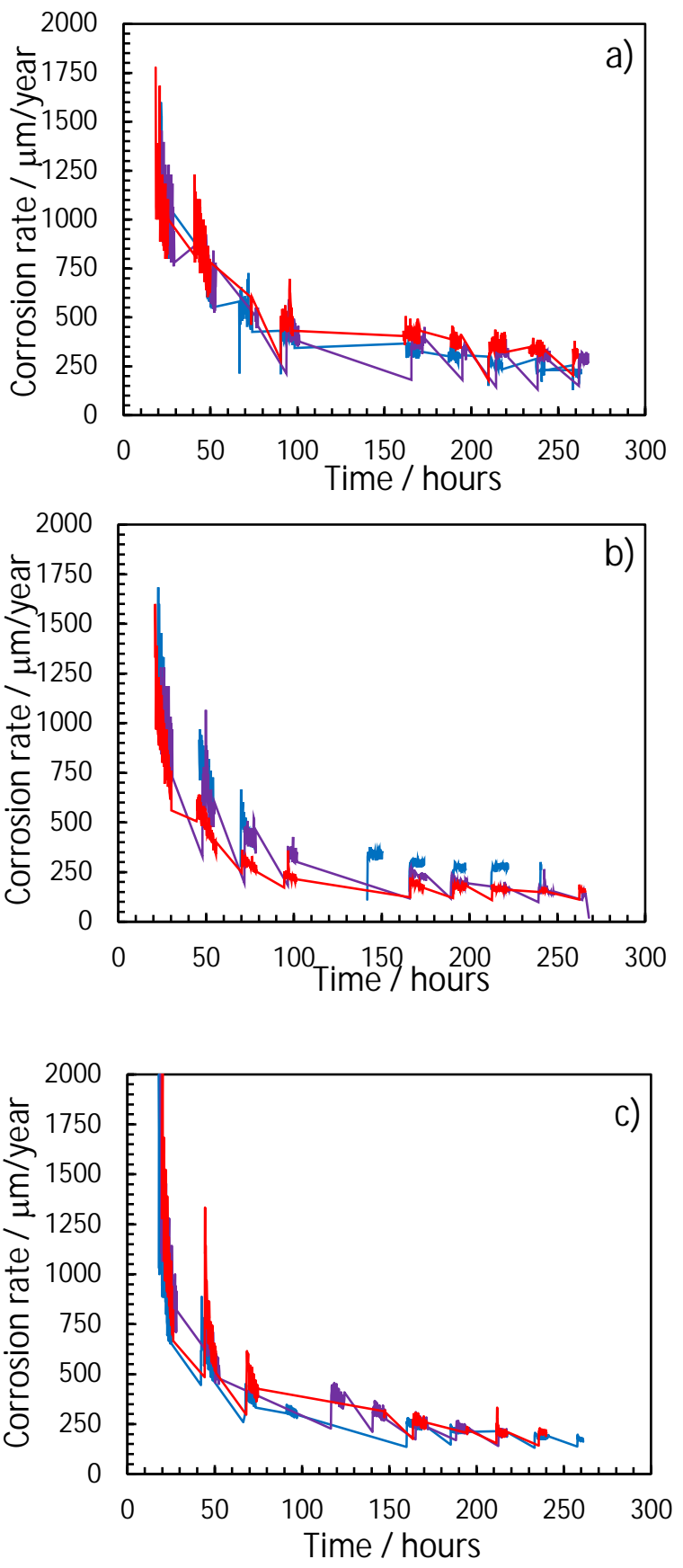

Fig. 2. Instantaneous corrosion rate of mild steel in how tap water $\left(50{ }^{\circ} \mathrm{C}\right)$, determine with LPR technique at different flow rate $(a-0.15 \mathrm{~m} / \mathrm{s} ; b-0.30 \mathrm{~m} / \mathrm{s} ; c-0.45 \mathrm{~m} / \mathrm{s})$ and water supply rate (Blue - $0 \%$; Pink - $35 \%$; Red-70\%). 
Only at the highest tested flow rate of $0.45 \mathrm{~m} / \mathrm{s}$ the barrier layer is formed faster than calcium is depleted, thus steady corrosion value $i_{0}$ is low (179 $\mu \mathrm{m} /$ year $)$. Similar situation is observed at the lowest flow rate $0.15 \mathrm{~m} / \mathrm{s}$. The steady corrosion remains high at this flow rate at every tested supply rate.
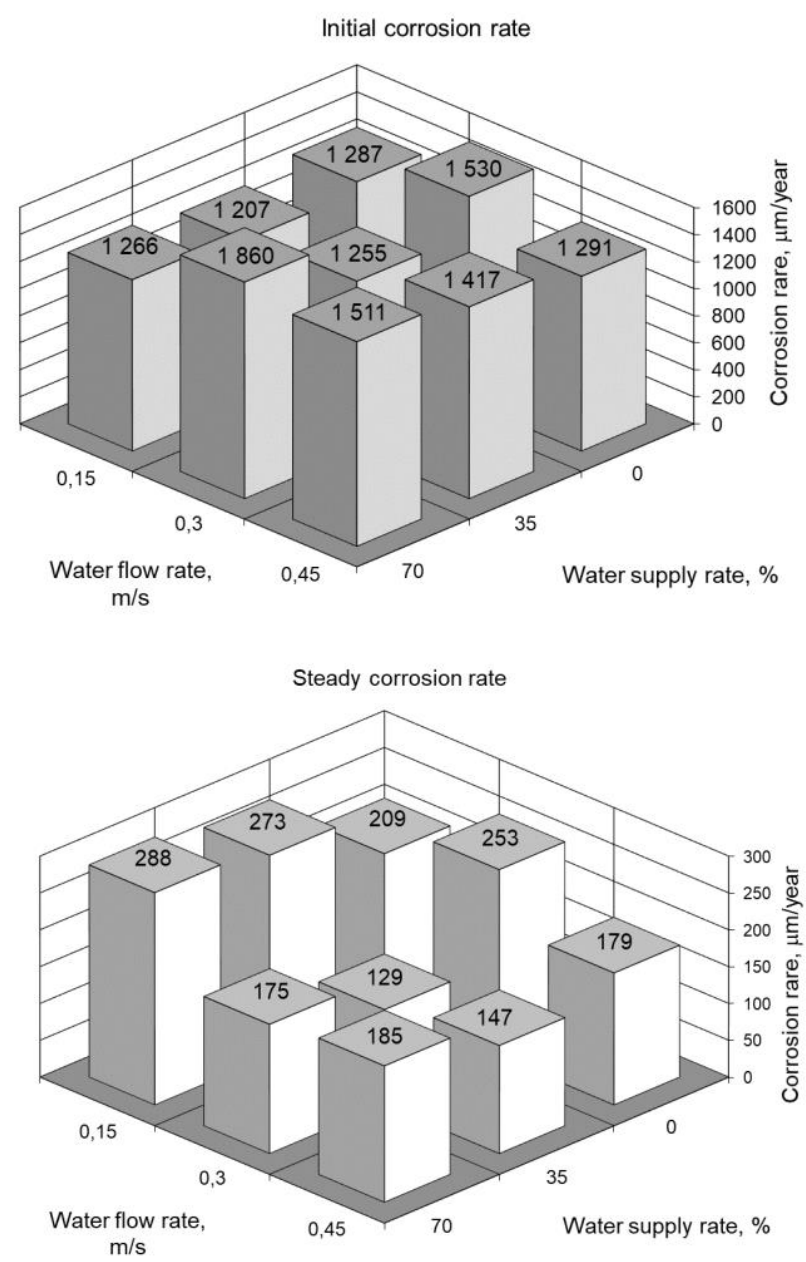

Fig. 3. Diagrams showing reciprocal influence of water flow rate and water supply rate on corrosion of mild steel in hot tap water.

The reason for this is that the rate of oxygen reduction and calcium supply is insufficient to form reliable barrier layer. Corrosion products formed at this flow rate are loose and porous and does not provide sufficient protection from further corrosion. The increase in both water flow and supply rates enables the formation of dense and adherent corrosion products layer on the steel surface, which provides reliable corrosion protection, corrosion rate is reduced from 0.29 to $0.18 \mathrm{~mm} /$ year.

The XRD analyses of the deposits are given in Fig. 4. On the most of the diffractograms the peaks of calcium carbonate and iron oxides can be identified, however the crystallinity of the deposits is different. At the lowest flow rate the deposits are poorly crystallized, meaning the most compounds are amorphous $\mathrm{Fe}(\mathrm{OH})_{3}$. Only one peak corresponding to calcite was detected. Better crystallinity is observed at higher water flow rates. Lower noise level and sharp characteristic peaks are observed at flow rates $0.30-0.45 \mathrm{~m} / \mathrm{s}$ and supply rates $30-70 \%$.

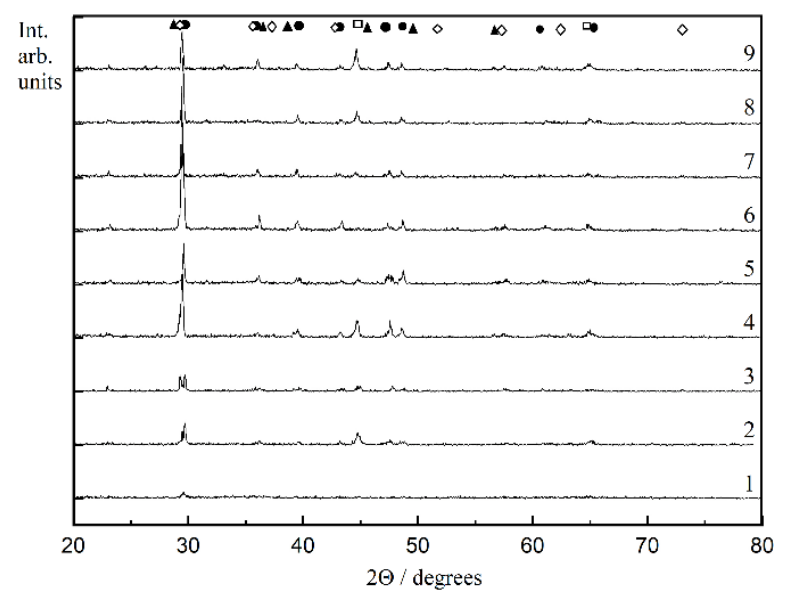

Fig. 4. XRD patterns of surface deposits, formed on mild steel in tap water at different flow rates $(F)$ and supply rates $(S): 1$ $-F-0.15 \mathrm{~m} / \mathrm{s}, S-0 \% ; 2-F-0.15 \mathrm{~m} / \mathrm{s}, S-$ $30 \% ; 3-F-0.15 \mathrm{~m} / \mathrm{s}, S-70 \% ; 4-F-$ $0.30 \mathrm{~m} / \mathrm{s}, \mathrm{S}-0 \% ; 5-F-0.30 \mathrm{~m} / \mathrm{s}, \mathrm{S}-30 \%$; $6-F-0.30 \mathrm{~m} / \mathrm{s}, S-70 \% ; 7-F-0.45 \mathrm{~m} / \mathrm{s}$, $S-0 \% ; 8-F-0.45 \mathrm{~m} / \mathrm{s}, \mathrm{S}-30 \% ; 9-F-$ $0.45 \mathrm{~m} / \mathrm{s}, \mathrm{S}-70 \%$; - - calcite; $\square-$ iron; $\diamond$ iron oxide; $\boldsymbol{\Delta}$-iron oxyhydroxide. 
Peak identification shows the presence of calcium carbonate in the form of calcite and iron oxyhydroxides, namely goethite, akaganeite and lepidocrocite. XRD confirms the influence of water flow and supply rates on the structure of the deposits formed on the steel surface.

Considering the obtained results, some further recommendations to improve the performance of hot water supply systems can be proposed. For the water supply systems with mild steel pipelines, it is recommended to maintain water circulation with flow rate $0.3 \mathrm{~m} / \mathrm{s}$ and higher and water supply rate at least of $30 \%$ of system volume per hour, in order to keep oxygen and calcium carbonate concentrations high enough to create efficient protective layer on the surface of steel. The lower flow rate leads to the formation of loose corrosion products badly attached to the surface. Flow rates above $0.45 \mathrm{~m} / \mathrm{s}$ may cause deposits erosion, thus enhancing the corrosion. Low water supply rates lead to the depletion of oxygen and calcium and efficient protective layer could not be formed. The maintenance of water flow rate above $0.3 \mathrm{~m} / \mathrm{s}$ and water supply rate above $30 \%$ results in 1.6-time steel corrosion rate reduction.

\section{Conclusions}

The influence of water flow rate and water supply rate on the formation and protection properties of corrosion products formed in hot water supply system has been investigated. The following conclusions can be drawn out.

The water flow rate lower than $0.15 \mathrm{~m} / \mathrm{s}$ and water supply rate lower than $30 \%$ of the systems volume per hour does not provide the formation of efficient barrier layer of corrosion products on the surface of mild steel in hot tap water. The corrosion rate is stabilized at $0.25-0.30 \mathrm{~mm} /$ year. According to XRD analysis, the formed corrosion products are poorly crystallized, and mainly consist of amorphous $\mathrm{Fe}(\mathrm{OH})_{3}$.

The increase of water flow rate higher than $0.30 \mathrm{~m} / \mathrm{s}$ and water supply rate over $30 \%$ of the systems volume per hour leads to corrosion rate reduction at least in 1.6 times due to formation of dense and adherent corrosion products consisting of calcium carbonate and iron oxyhydroxide.

The results obtained in the present study can be utilized to improve the corrosion performance of hot water supply systems by controlling water flow and supply rates and thus will help to improve water quality, reduce failure risk, and expand the metal pipes operation time.

\section{Acknowledgements}

This work was supported by the Ministry of Education and Science of Ukraine [grant number 2044, 2017].

\section{References}

Antoun, E. N.; Dyksen, J. E.; Hiltebrand, D. J. Unidirectional Flushing: A Powerful Tool. $J$. Am. Water Works Assoc. 1999, 91 (7), 62-72. https://doi.org/10.1002/j.1551-

8833.1999.tb08665.x.

Deslouis, C.; Festy, D.; Gil, O.; Rius, G.; Touzain, S.; Tribollet, B. Characterization of Calcareous Deposits in Artificial Sea Water by Impedance Techniques-I. Deposit of $\mathrm{CaCO} 3$ without $\mathrm{Mg}(\mathrm{OH})_{2}$. Electrochim. Acta 1998, 43 (97), 1891-1901. https://doi.org/10.1016/S00134686(97)00303-4.

Elbeik, S.; Tseung, A. C. C.; Mackay, A. L. The Formation of Calcareous Deposits during the 
Corrosion of Mild Steel in Sea Water. Corros. Sci. 1986, 26 (9), 669-680.

https://doi.org/10.1016/0010-938X(86)90032-6.

Henderson, A.; Roberts, L.; Bogan, J.; Rubin, C. H.; Semenza, J. C. Water Distribution System and Diarrheal Disease Transmission: A Case Study in Uzbekistan. Am. J. Trop. Med. Hyg. 1998, 59 (6), 941-946.

https://doi.org/10.4269/ajtmh.1998.59.941.

Herasymenko, Y. S.; Vasyl'ev, H. S. A Two-Step Method for the Evaluation of Corrosion Rate in Metals. Mater. Sci. 2009, 45 (6), 899-904. https://doi.org/10.1007/s11003-010-9256-6.

Hilbert, L. R. Monitoring Corrosion Rates and Localised Corrosion in Low Conductivity Water. Corros. Sci. 2006, 48 (12), 3907-3923. https://doi.org/10.1016/j.corsci.2006.03.004.

Liang, J.; Deng, A.; Xie, R.; Gomez, M.; Hu, J.; Zhang, J.; Ong, C. N.; Adin, A. Impact of Flow Rate on Corrosion of Cast Iron and Quality of Re-Mineralized Seawater Reverse Osmosis (SWRO) Membrane Product Water. Desalination 2013, 322, 76-83.

https://doi.org/10.1016/j.desal.2013.05.001.

Lyon, S, Richardson, T (ed.), Cottis, B (ed.), Lindsay, R (ed.), Scantlebury, D (ed.), Stott, H (ed.) \& Graham, M. (ed. . Shreir's Corrosion.; 2010.

Tamura, H. The Role of Rusts in Corrosion and Corrosion Protection of Iron and Steel. Corros. Sci. 2008, 50, 1872-1883. https://doi.org/10.1016/j.corsci.2008.03.008.

Valdez, B.; Schorr, M. Corrosion Control in the Desalination Industry. Adv. Mater. Res. 2010, 95,
29-32.

https://doi.org/10.4028/www.scientific.net/AMR. 95.29.

Vasyl'Ev, H. S. Measurement of Polarization Resistance with Computer Logging of Results. Mater. Sci. 2013, 48 (5). https://doi.org/10.1007/s11003-013-9556-8.

Vasyliev, G. Polarization Resistance Measurement in Tap Water: The Influence of Rust Electrochemical Activity. J. Mater. Eng. Perform. 2017. https://doi.org/10.1007/s11665-017-2813-5.

Vasyliev, G. S. The Influence of Flow Rate on Corrosion of Mild Steel in Hot Tap Water. Corros. Sci. 2015, 98, 33-39. https://doi.org/10.1016/j.corsci.2015.05.007.

Vasyliev, G. S.; Gerasimenko, Y. S.; Poznyak, S. K.; Tsybulskaya, L. S. A Study of the Anticorrosion Properties of Carbonate Deposits to Protect Low-Carbon Steel from the Action of Tap Water. Russ. J. Appl. Chem. 2014, 87 (4), 450455. https://doi.org/10.1134/S1070427214040090.

Vasyliev, G. S.; Vasylieva, S. M. The Influence of Ultrasound on the Carbonate Cathodic Crystallization in Artificial Potable Water. J. Electrochem. Soc. 2017, 164 (4), H250H256. https://doi.org/10.1149/2.0301706jes.

Vasyliev, G.; Brovchenko, A.; Herasymenko, Y. Comparative Assessment of Corrosion Behaviour of Mild Steels 3, 20 and 08KP in Tap Water. Chem. Chem. Technol. 2013, 7 (4), 477-482. 


\title{
ПІДВИЩЕННЯ КОРОЗІЙНОЇ СТІЙКОСТІ МАЛОВУГЛЕЦЕВОЇ СТАЛІ У ВОДОГІННІЙ ВОДІ: ВПЛИВ ШВИДКОСТІ ПОТОКУ ТА ПІДЖИВЛЕННЯ
}

\author{
Г. С. Васильєв \\ Національний технічний університет України \\ «Київський політехнічний інститут імені Ігоря Сікорського»
}

\begin{abstract}
Корозію маловуглечевої сталі досліджено в гарячій водопровідній воді $\left(50{ }^{\circ} \mathrm{C}\right)$, використовуючи метод поляризаційного опору в лабораторній установиі, щуо моделює циркуляиійну систему. Досліджено вплив витрати води (0,15-0,45 м/с) та рівні підживлення води (0-70 \% від об'єму системи на годину) на кінетику корозії. Продукти корозії, щяо утворюються на поверхні сталевих датчиків корозіі, аналізували за допомогою методу рентгенівської дифракції (XRD). Встановлено, щзо в умовах низької витрати води (0,15 м/с) та за відсутності піджсилення швидкість корозії висока (0,29 мм/рік) через низькі блокуючі властивості поверхневих відкладень. Аморфний $\mathrm{Fe}(\mathrm{OH})_{3}$ є основним продуктом корозї, який можна виявити на поверхні. Збільшення швидкості потоку води вище 0,15 м/с і швидкості подачі води вище 30 \% від об'єму системи на годину призводить до зниження швидкості корозії в 1,6 рази (до 0,18 мм/рік) за рахунок утворення щільного поверхневого шару карбонату кальиію та оксигідроксидів феруму. Отримані результати можуть бути використані для поліпшення корозійного стану систем гарячого водопостачання.
\end{abstract}

Ключові слова: швидкість корозії, витрата води, маловуглецева сталь, поляризаційний опір, водопровідна вода 